\title{
Towards an Eco-decolonial Museology: A critical realist analysis of the crises of South African museums
}

\author{
Tom Jeffery, Amazwi South African Museum of Literature, South Africa
}

\begin{abstract}
South African museums face multivalent, simultaneous crises. The MELD dialectical framework of critical realist philosophy can be used to explore potential for a deep reimagining of museum theory and practice that may generate a new, relational mode better able than persistent dualist modes to respond to complex, emergent crises. This has been conceived by the author (Jeffery, 2021) as an ecological-decolonial, or eco-decolonial, mode of museology, and is further developed in the present analysis.

At $1 \mathrm{M}$, the MELD analysis surfaces the implicit neoliberal ontology of South African museum work and the emergent paradox of 'emancipatory neoliberalism'. This paradox is generative of a number of constraints on practice and agency, including commodification of heritage, a restrictive form of official memory, and quantitative management practice. These limit potential for museums to respond to complex crises that require relational capabilities.
\end{abstract}

$2 \mathrm{E}$ explores the potential negation of these constraints. To disrupt the principle of collection as the grounding ontological activity of museum practice may disrupt the implicit neoliberal ontology. This may contribute to emergent, sophisticated socialecological trends in museum practice, both in South Africa and internationally.

At 3L, a dialectical view on the concept of cultural landscape offers a relational frame for an eco-decolonial museum practice that may better respond to the crises faced by museums. The practical implications of the eco-decolonial approach are considered at 4D.

Keywords: museum practice, critical realism, ontology, eco-decolonial, collection, cultural landscape

\section{Introduction and background}

In the South African context, the potential of museums as complex and dynamic learning environments (Kristinsdóttir, 2017, p. 424) is constrained by at least three concurrent and entangled moments of crisis for practice. These are: the global social-ecological crisis; a crisis of identity and relevance that is the subject of decolonial critique and that the analysis below 
will surface as an ontological crisis; and the emergent crisis of the COVID-19 pandemic. These crises illuminate and give insight into the museum as a social structure. What do these crises mean in terms of the agency of museums and museum workers, and the agency they may enable through public programmes of exhibition and learning? What do they mean for the future sustainability of South African museums as educational institutions? What pathways may chart fresh transformational potentials for museum practice?

Forms of museum practice with potential to explore the dynamics of social and ecological processes as interlinked systems are becoming increasingly urgent (Anderies, Janssen \& Ostrom, 2004, p. 2; Walker et al., 2004, p. 1). Decolonisation and ecologisation of practice are current museological trends that have particular relevance to this. The ecologisation of museology refers to emergent ways of thinking that disrupt persistent human-nature dualism and emphasise the relationship between humanity and the environment as mutually constructive (Plumwood, 2002; Allen, 2015; Newell, Robin \& Wehner, 2017; Phillips, 2019).

Decolonisation can be considered as a process of empowerment of marginalised peoples and demarginalisation of associated knowledge and traditions (Dondolo, 2005; Alonso, 2008; Mdanda, 2016). South African museums continue to focus on amelioration of the depredations of the colonial and apartheid eras, the memorialisation of a difficult heritage, and on inclusivity, representivity and relevance (Corsane, 2004; Mosely, 2007; Bakker \& Müller, 2010; Meskell, 2012; Macdonald, 2015). Relational, social-ecological perspectives are largely absent from the primarily social focus of South African decolonial museology (Jeffery, 2017). This is a constraint that limits the decolonial perspective and hinders decolonisation, and for which this article will consider potential resolutions.

Earlier work (Jeffery, 2021) introduced the idea of an ecological-decolonial, or ecodecolonial mode of museology. This is a new form of museum practice that disrupts traditional museological dualism by emphasising the interlinked dynamics of social and ecological processes mentioned above, and with potential to generate a relational mode of museological thinking and practice that is grounded in the entanglement of the decolonial (social) and ecological crises. The eco-decolonial approach to museology will be further developed in the present analysis.

A dialectical critical realist analysis surfaces neoliberalism as the implicit ontology (Bhaskar, 2008) of museum work, that is, as the underlying ontology that drives practice. This ontology is not generally a subject of museological critique. To disrupt the implicit ontology is a vital first step in negotiating museums' crises of identity and relevance and is potentially generative, in the museological context, of the multidisciplinarity Bhaskar (2010) identified as vital to the practice of the social sciences in the context of socialecological crisis. This ontological work is vital if South African museums, as potentially crucial centres of non-formal education, are to be able to respond more effectively both to rapidly emergent and longer term crises.

For the entirety of their post-apartheid existence, South African museums have been struggling to reinvent themselves for new, diverse audiences and emergent needs. This struggle, within an emergent snarl of crises, and together with the International Council 
of Museums' (ICOM) current process of redefinition of the museum (ICOM, 2007), represents a moment of fluidity in which museums may radically reimagine themselves. This reimagining must necessarily have a relational perspective on the entangled social and ecological crises that characterise post-apartheid museums' practice context. Socialecological relationality is the foundation of the eco-decolonial mode of museology. As was emphasised in previous work, this offers a fresh way of thinking in order to disrupt the persistence of human-nature dualism and to expand museological theory and practice to emphasise the relationship between humanity and the environment as mutually constructive (Jeffery, 2021).

\section{Why dialectical critical realism?}

Dialectical critical realism is notoriously complex, but it is very valuable to the understanding of social structures such as museums, and the mechanisms that steer practice in particular directions (Lotz-Sisitka \& Price, 2016; Price, 2016). The philosophy of dialectical critical realism (henceforth DCR) offers "explanatory tools and forms of reasoning that allow for making the complexities found in our contexts more visible and open for dialogue, engagement, learning and reflexivity" (Lotz-Sisitka \& Price, 2016, p. 5), and therefore has potential to contribute to the emergence of progressive modes of museological theory and practice better able to respond to crisis.

The contemporary museum, with its persistent dualist foundation that separates social from ecological perspectives, is easily perceived as operating separately from the concerns of the world today, focused too much on the past, and "ill-equipped philosophically and ontologically" to face the challenges of a "messy and turbulent world" (Cameron, 2015a, p. 345). The application of critical perspectives to the museum context is vital if museums are to remain socially relevant (Vergo, 1990; Smith, 2014). Vollgraaff's (2018) comprehensive survey of the South African Museums Association Bulletin identified an absence of socialecological themes and concluded that South African perspectives lag behind international museological thinking (also see Levitz \& Mathers, 2000; Martin, 2000; Jeffery, 2017; Jeffery, 2021). This implies a need to develop the philosophical and theoretical perspectives that shape South African museum practice. DCR was chosen to act as a philosophical 'underlabourer' for such processes, as elaborated below.

The complexity of DCR is reflected in some of the language that comes with making use of it. The analysis below is hopefully accessible, but the goal of this article is to draw new philosophical and theoretical perspectives into museology's approaches to difficult and complex contexts, and this necessarily comes with new concepts and new language.

DCR, however, potentially removes constraints on transformation and enables progress towards social-ecological justice (Bhaskar, 2008; Lotz-Sisitka, 2016; Mukute, 2016; Schudel, 2017). It can thus be deeply useful for generating practical change in transformative contexts such as that of South African museum practice. If the language is sometimes unfamiliar and challenging, as it was indeed found to be during the research for this and previous articles, it is hoped that the reader will approach this challenge from the 
perspective of generating valuable new ways of thinking with the potential to further the vital agenda of social-ecological transformation.

\section{Research methodology}

The analysis makes use of abduction and induction as guided by the MELD framework introduced by Bhaskar (2008; also see Hartwig, 2008). Abduction refers to the recontextualisation of existing knowledge (Togo, 2016), and the work here draws in themes or codes from earlier work (Jeffery, 2017; Jeffery, 2021). An initial exploration of postapartheid South African heritage policy and museum practice (Jeffery, 2017), for instance, identified an absence of ecological issues from museum practice, generated by their absence from the policy framework, and highlighted a need to link ecological and decolonial concerns in order to bring about the emergence of meaningful transformations of museum practice. A deep $1 \mathrm{M}$ contextual analysis of the causal mechanisms of restrictions on postapartheid South African museum policy and practice (Jeffery, 2021) located contemporary South African museology in the context of emergent international museological trends. This is the basis for the $1 \mathrm{M}$ analysis conducted here.

Induction refers to the identification of new codes from the data at hand, "a process that ... helps us to [move] from a set of observations to a theory" (Sabai, 2016, p. 182) and to "surface general premises that may inform changes to practice" (ibid., p. 183). A review of literature enacts induction of new codes. The progress through the MELD schema in the analysis below moves from abduction of $1 \mathrm{M}$ codes from previous work (which are emphasised below because of their importance to the analysis) to the induction of new codes at 2E, 3L and 4D. Through abduction and induction, the analysis explores and develops the practical transformative potential of the eco-decolonial mode of museology as a new, relational approach to the resolution of the crises outlined in the introduction and which are faced by South African as well as international museums.

\section{Philosophical methodology: Dialectical critical realism as underlabourer}

Underlabouring can be understood as "the process of clarifying ... ontological and epistemological confusions and uncertainties [to support] a transformative research intent" (Bhaskar, 2008, p. 335) or the practice of philosophy for real social-ecological change (see also Bhaskar \& Parker, 2010; Price, 2016; Rosenberg, 2020a). DCR specifically looks to the "re-vindication of ontology ... the philosophical study of being, as distinct from and irreducible to epistemology" (Bhaskar, 2010, p. 1) and "stresses the crucial role that being (ontology) plays in our ... efforts to understand the way things are" (Norrie, 2010, p. 7). As such, it has potential to equip museums to meet the urgent philosophical and ontological challenges to which Cameron refers (2015a), and to further the museological goal of transformation towards the betterment of peoples' lives (Weil, 1999; Ballantyne \& Uzzel, 2011). To think of DCR as 'underlabourer' is to think of it as a philosophical support system, a system that enables practical change by offering new ways to understand, critique and change the real conditions of practice. 
DCR is here proposed as underlabourer to the development of the emancipatory potentials of museological philosophy, theory and practice. This development relates the South African context to an emergent, and yet tentative, international critique of dualist museological structures (Cameron, 2015a; Cameron, 2015b; Newell et al., 2017; Jeffery, 2017; Wehner, 2017; Jeffery, 2021). DCR offers new potentials to disrupt dualist constraints on practice, that is, to disrupt the entrenched historical museological division between social and ecological perspectives and the restrictions that are generated by this division. This enables progress towards the relational, eco-decolonial mode that may bring greater freedom to "humanity-in-nature" (Moore, 2017, p. 598).

One of the important philosophical contributions of DCR to understanding complex contexts is its stratified or layered approach to reality. DCR initially conceives three ontological domains: the real (that which exists independent of human experience), the actual (the moment at which human experience 'discovers' the real and interacts with it), and the empirical (cultural mediation of the real and the actual) (Bhaskar, 2010; Price, 2016; Rosenberg, 2020a). The epistemic fallacy, which is significant to the analysis below, is the reduction of the domain of the real to the domain of the actual, and the reduction of ontology to epistemology.

The epistemic fallacy is the representation of epistemology (a specific interpretation of the world) as ontology (a state of being, or the real way the world is, and without alternative). This process "functions merely to cover the generation of an implicit ontology" (Bhaskar, 2008, p. 4; Bhaskar, 2010, p. 1), and the epistemic fallacy is thus potentially a manipulation of knowledge to the benefit of restrictive forces. Identifying instances of the epistemic fallacy can focus attention on deep ontological issues, and on the deep causal mechanisms of the restrictions on practice that are of interest in the present analysis. This will be explored below in the context of capitalist dualism and its neoliberal ideology and the ways in which these have come to constitute the implicit ontology of museology (explored in depth in Jeffery (2021), and as outlined above presented abductively here). This ontology has profoundly negative impacts on the transformation of the museum as a social structure and on the ability of museums to offer agency to people.

\section{Dialectical critical realism and the MELD schema}

MELD is "a robust schema for investigating ... research contexts concerned with societal transformation," and a means through which normalised practice can be expanded reflexively (Lotz-Sisitka, 2016, p. 318; Schudel, 2017, p. 163). The MELD schema (see Figure 1) structures the analysis below as it looks for potentials to remove constraints on transformation towards social-ecological justice in museology. The character of each moment is outlined at its start. Figure 1 gives an overview of the MELD schema. The bidirectional arrows show the relational nature of the process. 


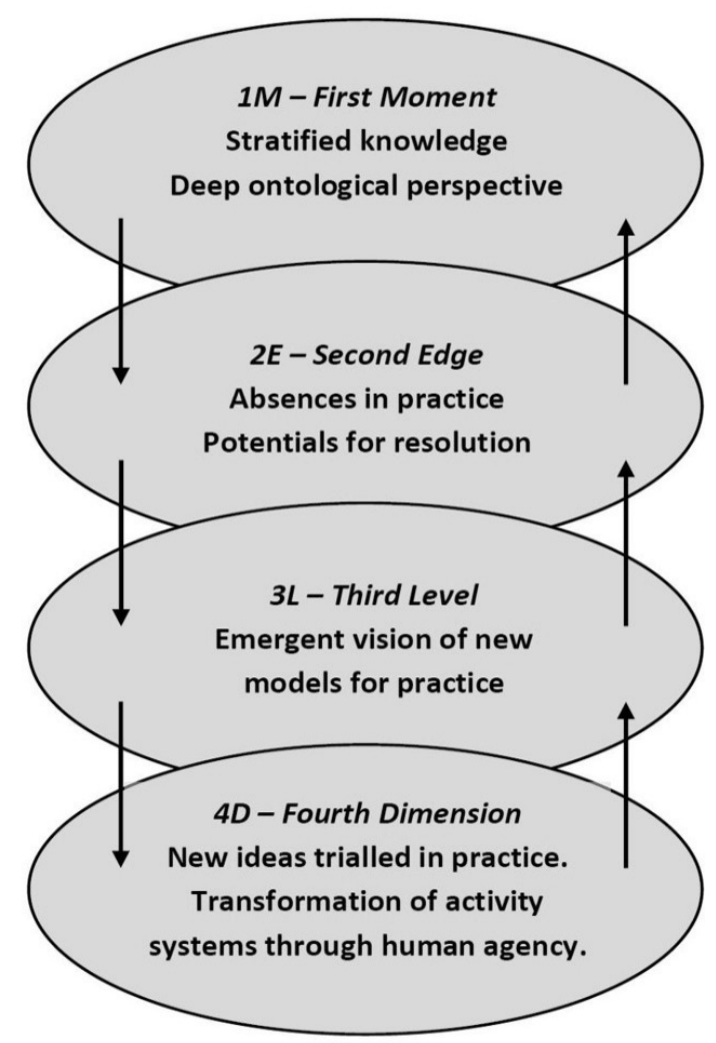

Figure 1: Overview of the MELD schema (developed by the author)

\section{M: Depth ontology}

$1 \mathrm{M}$ enables a deep understanding of the status quo, through "the intrication of a multiplicity of explanatory mechanisms" (Bhaskar, 2008, p. 196; see also Bhaskar, 2010; Fletcher, 2017). DCR views the world as constituted by real, open systems in which phenomena are generated by an array of driving impulses (Bhaskar, 2010). In the stratified DCR perspective on the world, this generative structure is conceived as a lamination of intersecting levels that interact in emergent ways (Bhaskar, 1998; Bhaskar, 2010; Lotz-Sisitka, 2016). The relational 'seven laminations of scale' model tracks emergence through: 1) the cosmological or planetary level, 2) the mega level of civilisations, 3) the macro level of policy and ideology, 4) the meso level of formal practice, 5) the micro level of social interaction, 6) the individual or biographical level, and 7) the sub-individual, psychological level (Bhaskar, 2010; Price, 2016). Each level is emergent from but also influences those previous, a relational perspective on the interconnected nature of the world that helps researchers to avoid relativism and reductive, linear philosophies such as dualism (Cameron, 2015b; Rosenberg, 2020a). This deep, retroductive ontological perspective seems vital in the 
context of a crisis-ridden museum practice mired in historical dualism. Figure 2 gives an overview of the seven levels of the $1 \mathrm{M}$ moment, and represents the $1 \mathrm{M}$ generative complex of restrictions on museum practice.

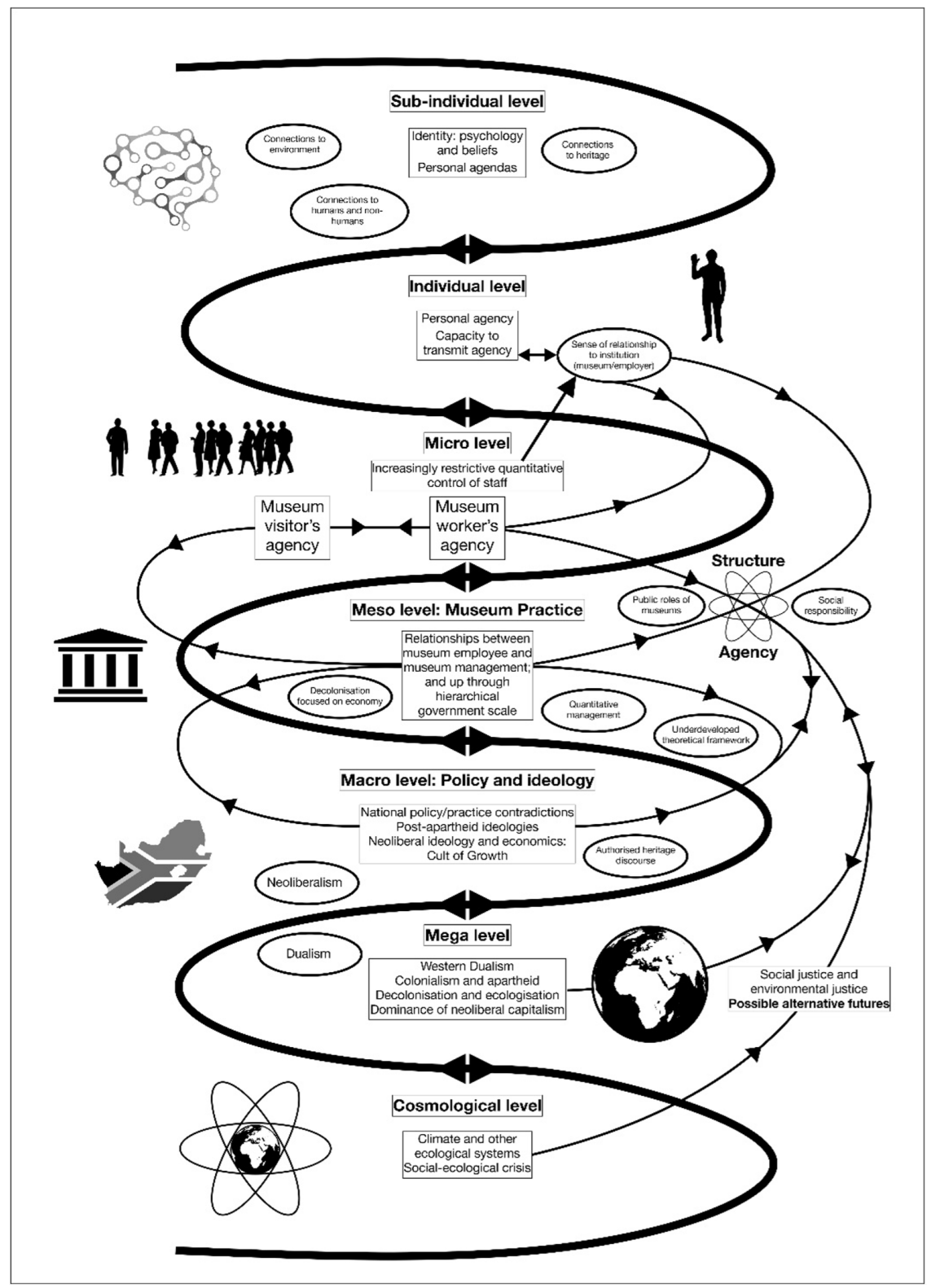

Figure 2: The seven levels of the $1 \mathrm{M}$ moment (developed by the author and reprinted with permission of Museum and Society) 
A detailed $1 \mathrm{M}$ analysis of the ontological context of museum work has been conducted elsewhere (Jeffery, 2021). In the limited space here, an abductive analysis focuses on the most crucial moments of the $1 \mathrm{M}$ emergence of neoliberalism as the implicit ontology of museum practice. This implicit ontology emerges as the most powerful restrictive force on museology (Jeffery, 2021), but is largely unrecognised because of the fundamental levels at which it operates (Jeffery, 2021). The disruption of this restrictive ontology is a primary goal of the eco-decolonial mode of museology, in order to potentially enable the emergence of more progressive and emancipatory forms of practice.

At the planetary level, the 'Anthropocene' proposition of humanity as a geological force (Crutzen, 2002) has been valuable in popularising understanding of human impacts on the planet, including in emergent museological approaches (Fox, 2017; Nixon, 2017; Robin et al., 2017). To conceive the present age as the Capitalocene illuminates "a system of power, profit and re/production in the web of life ... that not only accumulates capital, but drives extinction" (Moore, 2017, pp. 594-597). The Capitalocene perspective also reveals capitalism's "spaces of vulnerability and contradiction," (Moore, 2017, p. 595), such as the paradox of emancipatory neoliberalism elaborated below.

At the mega level (see Figure 2), the Capitalocene perspective surfaces neoliberalism as a global ideology reliant on human-nature dualism in the same ways as colonial capital (see Plumwood (2002, p. 8) on "our current failures and blindspots in relationships with nature"; and Plumwood (2002) and Moore (2015) on cheap nature and labour, and who counts as 'human'). Neoliberalism in the present analysis is considered as the ideology emergent from and supportive of the actual practices and impacts of dualist Capitalism on the real world. A significant facet of this ideology is the construction of 'real abstractions' such as Humanity, Nature, Society, the Economy (Moore, 2017). These can be understood as instances of the epistemic fallacy, which construct human-nature dualism as a given condition of reality (Moore, 2017). De Sousa Santos (2018) wrote that such manipulations reproduce the capitalist "cognitive empire" that elevates its contradictory and violent epistemology to ontology in a process which "take[s] away our ability to imagine or propose anything else without being made out to be wishful and irrational" (Rosenberg, 2020b, p. 2).

This perspective enables a critical view on the historical emergence of museological dualism from colonial capitalist dualism, and expands this critical view with the important understanding that museological dualism is perpetuated in the decolonial context by the contemporary dualism of neoliberal ideology. That is, current inequalities are not only colonial in origin and decolonial practice can be more effective if it has a focus on contemporary structures that are generative of restrictions on equality and freedom. The eco-decolonial perspective is that successive historical manifestations of capitalism thus restrict the emancipatory potentials of the museum and limit the responses of museum practice to crises.

At the macro level (see Figure 2), initial post-apartheid progress towards "a more social-democratic and co-ordinated variety of capitalism ... floundered as the government 
adopted neoliberal macroeconomic policies" (Nattrass, 2014, p. 56). The neoliberal policy framework is plagued by inconsistencies (Nattrass, 2014), and its practice by corruption and nepotism (see, for instance, Lannegren \& Ito, 2017; Budhram \& Geldenhuys, 2018), the net result of which is to exacerbate unemployment, for example, as Adjor and Kebalo described (2018), rather than to facilitate emancipatory social development.

The flow of neoliberal ideology from the mega to the macro level draws through the abstractions of the epistemic fallacy. Macro level South African policy echoes mega level international commitments to embed heritage within a neoliberal frame as the "cultural and creative industries" (Thomas, 2016, p. 37; Department of Arts and Culture, 2017). 'Optimal performance' is measured in relation to job creation, investment and economic growth as the solutions for social problems (South African Government, 2011; Kamga \& Heleba, 2012; South African Cultural Observatory, 2018). Macro level policy upon which decolonialism is premised thus proposes to counter the inequalities and violence of colonial dualist capitalism through the inequalities and violence of contemporary dualist neoliberalism, as powerfully described by Rob Nixon (2011) in his analysis of today's systematic international inequalities.

This paradoxical position undermines emancipatory practice potentials, and is a key element of the persistence of South African museums' crisis of relevance and their limited responses to social-ecological crisis. This is the crucial moment in which the implicit ontology of museum practice can be seen to be characterised by the emergence of the paradox of emancipatory neoliberalism. The development of relationality in museological philosophy and theory that was initiated in earlier work (Jeffery, 2017; Jeffery, 2021), and which this article further elaborates, is vital in order to disrupt this paradox and the limitations it places on the emancipatory potentials of museum practice.

Neoliberal ideology emerges at the meso level (see Figure 2) to govern formal relations between the institution (management) and employees, and determines the degree of agency workers may have to influence practice. These relations flow into the micro level to affect the degree of agency museum workers may have in interactions with communities and which they may transfer to communities through learning programmes. The agency of museum workers, as the executors of the museum's social responsibilities, is the agency of the museum itself. The close entanglement of issues of structure and agency (elaborated in more detail in Jeffery, 2021) enables a perspective on the dependence of agency, and thus social sustainability, on the flawed ontological structure of the museum, and shows why it is vital that transformation take place at an ontological level.

South African museum practice historically emerged from colonial western modes of dualist practice (Corsane, 2000; Abungu, 2004; Rall, 2018; Vollgraaff, 2018). Despite the emergent international critique referenced above, and even as ICOM redevelops its definition of the museum in order to better address contemporary challenges, the dualist practice frame remains entrenched (Cameron, 2015b; Jeffery, 2021). The full scope of a museum's meso level activities emerges from the practice of collection, such that collection is the grounding ontological activity of museum work. Collection practice is rooted in historical and neoliberal dualism, but is considered untouchable in the redefinition process: 
The museum definition should retain ... the unique, defining and essential unity in museums of the functions of collecting, preserving, documenting, researching, exhibiting and in other ways communicating the collections ... The word museum is easily understood in its manifold complexity, with a stable core concept of a collection. (Sandahl, 2018, p. 2; also see Sandahl, 2019)

As noted above, neoliberalism as a global ideology is reliant on human-nature dualism in the same ways as colonial capital. The defence of collection fixes the implicit colonial and neoliberal ontology and its dualist frame in contemporary museum practice and implicates museums in Capitalocene injustice.

Personal psychological agendas defined at the sub-individual level may be expressed at the individual level (Price, 2016; Togo, 2016). The museum workers' sense of their relationship with the institution may be empowering or disempowering, both personally and in relationships with users of the museum. The emergence of social-ecological practice trends and the progressive and nuanced positionalities expressed by South African museum workers (Jeffery, 2021) suggests tension between individual social-ecological positionalities and institutional neoliberal ideology. This may generate potentials for museum workers to resist contradictions and disrupt practice constraints. This and other potentials for transformation are explored in more detail at 2E.

\section{E: Absences and absenting}

$2 \mathrm{E}$ is "the point of transition or becoming" (Hartwig, 2008, p. xiii), concerned with identifying absences (which can be understood as social ills, untruths, injustice, or other constraints) in practice visible after the initial $1 \mathrm{M}$ analysis. DCR conceptualises change in terms of absence, as absence is ontologically prior to presence, which implies that the potential for emancipatory change lies within absences, and that to act with transformative agency can thus be viewed as a reflexive, dialectical act of the absenting (negation) of absences (Bhaskar, 2008). The absenting of absences is an emancipatory movement towards more adequate knowledge and the expansion of normalised practice.

Neoliberal constraint can be identified in the commodification of heritage practice, which constitutes a postcolonial reproduction of colonial hegemonies and restricts sustainability initiatives in favour of profitability (Helland \& Lindgren, 2016; Togo, 2016). The close association of heritage with tourism may reinforce and exploit cultural stereotypes as these are transformed into a consumable spectacle, while South African heritage governance structures see museums as tourist sites and not as knowledge-generating institutions (Rassool, 2000; Witz, Rassool \& Minkley, 2001; Marschall, 2005; Vollgraaff, 2018).

Several scholars have argued that 'official memory' emerges in the manipulation of meso level practices of memorialisation in relation to the values and material interests of political and economic elites (see for example Abungu, 2004; Shoba, 2005; Bakker \& Müller, 2010; Roux, 2018; Zuma, 2018). "Museums in South Africa are under pressure to adhere to a single, authorized narrative of the past and the present" (Vollgraaff, 2018, p. 385), a selective discourse of heroic leaders, of survival, triumph and exemplariness, that 
silences and alienates dissonant voices and communities, again noted by several critics (Rassool, 2000; Dubin, 2006; Soudien, 2008; Mngqolo, 2010; Rassool, 2016). The museum is instrumentalised in the construction of a specific identity, which despite the significant presence of the Apartheid Museum, readily absents deeper museological treatments of the "less remembered miseries and celebrations of township life" (Soudien, 2008, p. 211), as well as narratives of contemporary social-ecological injustice (Jeffery, 2021). Official memory can undermine the crucial role of arts and culture in social critique, and potentially discriminates against niche, experimental or radical programmes (Mahony, 2017).

Human creativity and agency are necessary for the achievement of the transformation of practice, and thus perhaps the most significant constraint of neoliberal ideology on museum practice is the strategic focus of museum management on rigid quantitative performance indicators, logistics, administration and Treasury compliance requirements (Vollgraaff, 2004; Dubin, 2006; Vollgraaff, 2018). The demands of compliance and economic measurements overshadow museological functions and effective museum services (Vollgraaff, 2018). Museum and heritage workers are alienated from the management system, and feedback into the system is limited (see De Shuman (2020) for a personal reflection on this structural condition). Potentials for creative worker-driven expansion of museum practice are absented by the limitations of economically correct practice. Neoliberalism generates a worker-institution binary that thus tends to consolidate dualist thinking (see Mahony (2017) on activist interventions against "corporatisation" of the practice of cultural institutions). Political and ideological structures constrain the agency of workers at the meso and micro levels in ways that ensure they are reproductive of structure. That is, neoliberal political and ideological structures prevent transformation even as they claim to champion them.

The stratified DCR perspective on reality shows how the paradox of emancipatory neoliberalism is generated and how it constrains practice so that, like policy, practice becomes an element of the neoliberal architecture. The implicit neoliberal ontology of museology perpetuates the historical injustices (absences) of colonial human-nature dualism, and most crucially, absents the relational social-ecological potentials for theory and practice that hold the most potential to enable transformation.

At least two entangled, practical, transformative pathways (means to absent these absences) surface from the $1 \mathrm{M}$ analysis. Firstly, tensions between traditional-institutional and progressive-individual museum workers' positionalities (Jeffery, 2021) generate potential for "interstitial" activism (Mahony, 2017) by museum workers. This is activism from within the ontological formation so that it may be 'opened up' from the inside, and which should be seen "not as an attack on these public institutions for their duplicitous value systems, but as acts of love for what they could be" (Mahony, 2017, p. 132). The sense of limited agency that an individual may feel within an institutional structure rooted in neoliberalism potentially manifests in resistance to its constraints. There is in this sense a personal level, as expressed by De Shuman (2020) above, to the ability or inability of museums to respond to crises. This potential may inform the $3 \mathrm{~L}$ vision and be explored 
in practice at $4 \mathrm{D}$, particularly in terms of the ways in which it may facilitate the second transformative pathway.

Neoliberalism is the implicit ontology, and collection is the grounding ontological activity of museum work. While the methods of collecting, and of interpreting and exhibiting collections are the focus of critique, reflection, and change (Pearce, 2003; Morgan \& Macdonald, 2020), the principle of collection is so fundamental to what a museum is conceived to be that it seems to be exterior to processes of formal change intended to reinvent the museum and ensure its future (Sandahl, 2018). This effectively applies a philosophical shield to the deep ontological roots of museological dualism and the ways in which this reflects the colonial hierarchy of culture as superior to nature and cultures themselves as similarly hierarchical (Cameron, 2015b). This hierarchical ordering is equally vital to the implicit neoliberal ontology that underpins post- and decolonial practice and, again, remains as reliant on dualism as was colonial capital (Moore, 2017).

Human-nature dualism thus continues to frame the work that museums do because of the absence of critique directed at the ontological and ideological significance of the practice of collection. "Core museum functions and societal responsibilities are not in competition with each other" (Sandahl, 2019), but the absence of reflexivity directed at the ontological significance of collection, as the core activity of museum work, generates an absence of coherence between the theoretical social-ecological responsibilities and the actual practice of museum work. The ontological alignment between the museological practice of collection and oppressive ideology is why there is a pressing need for new forms of reflexive and disruptive social-ecological relationality in theory and practice, such as the eco-decolonial mode of museology (as proposed in Jeffery, 2021). Rather than being hidden and protected, collections may be positioned at the heart of the 'ideological faultline' of tensions between traditionalist and progressive museologies (Adams, 2019a; Adams, 2019b). The ways in which the eco-decolonial mode of museology may disrupt the untouchable position of the principle and practice of collection may thus contribute to resolution of the fundamental ontological paradox of emancipatory neoliberalism.

This moment of multiple crises and potentials for their resolution is one in which museum practice might be reimagined, and this will be the focus of the $3 \mathrm{~L}$ analysis.

\section{L: A vision for museum practice}

3L develops the emergent vision of the open system that is being studied, "the inner truth or pulse of things and the spot from which we must act" (Bhaskar, 2008, p. 8; see also Schudel, 2017). 3L is about exploring possibilities in the newly understood context, and initiates a vision for the world in which social-ecological justice predominates (Schudel, 2017). A relational point of view is emphasised as new models for practice are imagined (Bhaskar, 2008; Norrie, 2010; Mukute, 2016), in this instance the relationality of the eco-decolonial mode of museology with its social-ecological foundation.

The fundamental shift envisioned in the development of the eco-decolonial approach is an ontological transformation across Adams' 'ideological faultline' (2019a; 2019b) from 
traditionalist human-nature dualism to a progressive human-nature dialectic. The idea of cultural landscape offers a suitable theoretical frame for this ontological shift, as it is one with which the heritage sector is familiar and which demonstrates emergent relational, social-ecological potentials.

Perspectives on cultural landscape have a presence in various ICOM documents (see Garlandini (2016) for a summary of the broad ICOM position on cultural landscape). Most institutional conceptions of cultural landscape are routinely instrumental, dualist, even gendered, 'nature and man' perspectives in which environmentalism is subaltern to overarching 'cultural forces' (UNESCO, 1972; Luengo, 2015; UNESCO, 2017). In the South African context, however, a more progressive perspective on cultural landscape is to be found in the 'Declaration on Museums and Cultural Landscape' (ICOM-SA and ICOMOSSA, 2016), which conceives a complex layering of cultural meanings associated with landscape. This encourages a relational perspective. The eco-decolonial approach develops this perspective to reimagine cultural landscape as a culture-landscape dialectic, which is a form of social-ecological dialectic. The eco-decolonial is thus a dialectical rather than a dualist mode of museum practice.

To reframe museological thinking and practice within a dialectic of culture-landscape opens potentials for emerging scholarship around relationality between culture and landscape (see, for instance, Crouch 2010) to disrupt human-nature dualism, the opposition at the heart of museology's ontological crisis. A perspective on situated knowledge of social-ecological crisis, that is, the knowledge of affected communities in affected sites (Haraway, 1988; Leino \& Peltomaa, 2012), emerges with potential to disrupt collection as the grounding ontological activity of museum practice. That is, there is potential for the eco-decolonial to be a situated form of practice and for this situated turn to disrupt the implicit museological ontology. This situated turn, which is discussed further at 4D, may focus museum theory and practice on the ways in which the amelioration of the colonial depredations of the past, and the resolution of museums' crises of identity and relevance, is entangled with the amelioration of the social-ecological crises of the present. The legitimacy of the eco-decolonial mode is dependent on such historical depth in its relational perspective.

Though dualist museology historically privileges the tangible, the intangible values associated with sites are always present and inseparable from material culture (Ntsoane, 2002; Department of Arts \& Culture, 2009; Sodano, 2017). In the post-colonial moment, the intangible is emphasised because of the urgent need for the demarginalisation of indigenous knowledge (Mungwini, 2013). This historic opposition can never be erased, but a dialectical eco-decolonial mode of practice may enable emergence of "a complex, coembedded, constellational relationship" (Norrie, 2010, p. 170) through which marginalised and dominant epistemologies may combine in new and interesting ways. The dialectical softening of the calcified distinctions between tangible and intangible, indigenous and colonial-scientific, between community memory (heritage, past) and community need (present and future), offers a logic for practice grounded in humanity's immersion in 
ecological systems and a spiritual communion with nature as source of life. This historicalimmersive logic is conceived as 'humanity-in-nature' in the eco-decolonial approach (adapting Moore's use of the term, 2017, p. 598). This adds further nuance to the ecodecolonial relationality that may facilitate a more progressive museological stance on the relationship between people and the environment, and enable greater potential to inform emancipatory learning and development.

Eco-decolonial relationality may be further deepened by nuanced Education for Sustainable Development (ESD) perspectives on intergenerational knowledge and learning around biodiversity loss:

\footnotetext{
Biodiversity loss as a global concern ... has shaped education imperatives towards learningled ... social-ecological change and intergenerational learning ... that might better situate indigenous peoples on their intergenerational lands in reflexive learning within a rich mix of ancient and modern scientific ideas and ideals. (O’Donoghue, Sandoval-Rivera \& Payyappallimana, 2019, p. 1)
}

The culture-landscape dialectic may draw on this to relate biodiversity loss as a global social-ecological concern to decolonial impulses focused on situated intergenerational knowledge. This emphasises that "the depth of historical wisdom and its intergenerational custodians must enter the sustainability game as key players towards attaining more just and sustainable futures" (O’Donoghue et al., 2019, p. 2). Rosenberg (2020b, p. 3), too, noted that "charting the way forward may ... require us to look back, to consider the almostforgotten wisdom from earlier times". There is eco-decolonial museological potential for intergenerational narratives of social relations to biodiversity to be co-curated by museums and communities into learning opportunities.

A dialectic of culture-landscape thus potentially offers an interdisciplinary practice frame that may deepen the emergent decolonial and ecological strands of museum practice and help bring them together into the relational eco-decolonial mode. From this fresh and progressive perspective may emerge patterns of reflexive and expansive learning that make available a new "ecology of knowledges" (De Sousa Santos, Arriscado \& Meneses, 2008, p. $\mathrm{xx}$ ) through which museums may surface means to address their ontological crisis and thus to engage more deeply with the social-ecological crisis.

An eco-decolonial museum practice drawing on this ecology of knowledges may focus on "supporting and curating networks of related things and their significance, rather than delivering knowledge from a single vantage point" (Newell et al., 2017, p. 2). The curated network, however, could focus on people as complex social-ecological entities and on their stories, rather than on 'things'. Progressive moves towards "collaborative ways of interpreting and relating to collections" (ibid.) could become a focus on collaborative ways of relating to people rather than objects, so that the grounding ontological activity becomes collaborative storytelling and the curation of community narratives. This may be facilitated by interesting tangible things, but the collection of things, even as the basis for narratives, is not necessarily the definitive operational focus of museum work. 
In the eco-decolonial mode the focus of museum work expands to include people and their stories and the culture-landscape in which they live and narrate as humanity-innature. The vision of an eco-decolonial museum practice is thus to disrupt traditional dualist practice through intergenerational story sharing within a dialectic of culture-landscape, and thus to disrupt the implicit neoliberal ontology.

\section{D: Potentials for change in context}

$4 \mathrm{D}$ is about "active and reflexive engagement within the world" (Bhaskar, 2008, p. 8). At $4 \mathrm{D}$, new ideas may be trialled in practice in order to bring real change to social structures through transformative human agency, which is how the eco-decolonial will move towards greater justice and the active resolution of social ills (Bhaskar, 2008; Hartwig, 2008; Schudel, 2017). 4D is the moment of real change in the practice context, through "the exercising of intentional and ethical human agency" (Mukute, 2016, p. 196). Interstitial activism, surfaced above as a transformative pathway for museum practice, may be exercised at 4D within the eco-decolonial culture-landscape dialectical practice frame imagined at 3L. Dualist museology may be disrupted by museum workers who, using the $1 \mathrm{M}$ understanding of its causal mechanisms, may assume the agency to become $4 \mathrm{D}$ agents for emancipatory change and locate themselves and their practice outside the neutralising paradox of emancipatory neoliberalism.

Interstitial activism may actively shift the focus of the grounding ontological activity of museum work towards a practice that includes the curation of situated social-ecological knowledge, "a movement ... towards interactive curatorial practices across physical and digital archives" (Hamer, 2019, p. 392). Physical archives are understood to transcend museums' storerooms to include land and landscape, natural ecological systems and natural heritage, the world-as-record and the human record of living in the world. Such physical archives are in the first instance real (in the DCR sense of that which exists independent of human experience) and prior to human interpretation. In the second instance, in the domain of the actual (the moment at which human experience 'discovers' the real and interacts with it), such physical archives are potentially generative of narratives that draw on intergenerational memory as a discursive practice. The persistent perception of museums as places of dead things and the dust of history (Thomas, 2016) is an element of South African museums' crisis of relevance. This may begin to be resolved through in situ active and practical engagements with peoples' living memories and perceptions of socialecological change, that is, through situated knowledge expressed in situated narratives.

3L surfaced potential for the emergence of a situated turn for eco-decolonial museology. In the $4 \mathrm{D}$ practical development of the situated turn, multidisciplinary scholarship in the culture-landscape dialectic may be brought into contact with actual, lived experiences. Situated knowledge may emerge in co-produced situated narratives of social-ecological crisis. The facilitation of situated narratives, to which Rogage et al. (2021, p. 2) refer using the evocative term "memoryscapes", is a means through which to generate meaning from experience (Philpott, 2014). This is also a means through which the eco-decolonial 
potentially shifts the museological ontology from a foundation in collections alone towards a foundation that draws in lived experiences of social-ecological reality.

"Museums ... are founded on positivist notions of certainty" (Cameron, 2015a, p. 348), and like Education for Sustainable Development (see, for instance, O'Donoghue et al., 2019), the eco-decolonial seeks to generate relationality between the historical divisions that have been set up by positivism and empirical realism. Museology, like ESD, can benefit from a relational perspective on western and intergenerational perspectives on place, ecological change and biodiversity, and the eco-decolonial mode can potentially accomplish this through engagements with situated knowledge. As noted at 3L, the eco-decolonial offers potential for marginalised and dominant epistemologies to combine in new and interesting ways.

A co-productive focus on facilitating the narration of the lived experience of people as complex social-ecological entities potentially enables museum practice to have greater relevance and sustainability than has been the norm in the dualist practice frame (Cameron, 2015b). The traditional focus of museology on expressing authoritative historical narratives can come into a dialectical relationship with contemporary contexts and experience in the co-production of emergent narratives in exhibition and learning programmes, which yet remain historically conscious.

More specifically, in the eco-decolonial mode of museology, the practice of collecting enters into a dialectical relationship with social-ecological reality (situated knowledge) and the practice of facilitating situated narratives. That is, eco-decolonial museum practice emerges from a dialectical relationship between collections and situated knowledge and narratives. Practice in effect becomes a dialectical act, the dialectic in action. This is a way to reimagine the dualist museum by reimagining the relationship between collections and society. Collection is the grounding ontological activity of museology, as elaborated above, and collection must thus be part of the new relational, dialectical ontology for museology, if collection is not to become part of a new dualism of collection versus situated narratives, or collection versus the eco-decolonial.

The emergence of this practice will be explored in more detail in forthcoming work, but it will focus on collaborative storytelling towards the co-production of exhibition and learning programmes in which the museum shares authority with the community. The traditional practice of collection and interpretation of objects is expanded by the situated narrative approach, an "expansion of normalised practice" (Lotz-Sisitka, 2016, p. 319) through which the eco-decolonial draws in a focus on people and their personal stories to disrupt the authority of the traditional museological focus on the interpretation of 'things'.

Situated narratives which emerge during fieldwork may be co-curated by the museum and narrators as evidence for the necessity of structural change in response to socialecological crisis. The eco-decolonial mode thus works towards the active resolution of museums' crises of identity and relevance while, at the same time, it works towards the amelioration of the social-ecological crises of the present, and carries out this work with awareness of historical contexts. Workers may thus disrupt the dualism of the implicit 
neoliberal ideology of museum work. This may revitalise the agency of museum workers and thus of museums, and consequently revitalise museums' capacity to enable agency for communities.

This practical mode of relating to collecting and to collected things is necessarily simultaneously cultural and ecological, and disruptive of dualism in that it requires multidisciplinary strategies for practice that bridge cultural and ecological studies, the humanities and the sciences. This represents the eco-decolonial operationalisation of a humanity-in-nature perspective for museum practice so that it is simultaneously and inseparably decolonial and ecological in impulse. That is, the decolonial and the ecological are not and cannot be separated.

\section{Future work}

Future work will develop the 4D moment. It will explore the practical potentials of the eco-decolonial mode in more detail and lay a path towards implementation. An important element of the development of the eco-decolonial mode of museology is the development of a multi- and interdisciplinary network of actors, as this is a vital catalyst for emergent socialecological practices (Bhaskar, 2010). Actors in this network will share the transformative agenda and the focus on thinking outside normalised ontology and practice. It is crucial to seek constructive relationships that may help in the generation of the eco-decolonial mode and that, most particularly, may offer constructive collaboration in learning to work in new ways and with new patterns of thinking. Cultural Historical Activity Theory will be employed during this process (see, for instance, Engeström, 2015).

This kind of multi- and interdisciplinary development may be understood as the development of a transformative knowledge network with transgressive learning capacities, a form of networking for learning that is potentially an important driver of change towards more sustainable practice (see, for instance, www.transgressivelearning.org for an overview of such networked potentials; also see Lotz-Sisitka et al., 2015; Lotz-Sisitka et al., 2016). Future work will make use of a constellational approach to the generation of a network of theoretical potentials that may contribute to the practical emergence of the eco-decolonial, and will explore potentials for the emergence of transgressive and expansive learning for sustainable museological practice.

\section{Conclusion}

A Dialectical Critical Realist MELD analysis surfaced neoliberalism as the implicit ontology of museum practice $(1 \mathrm{M})$, and considered potentials for ontological rejuvenation through disruption of the grounding ontological activity of museum practice, collection (2E). A dialectic of culture-landscape was envisioned as a fresh practice frame for museum work (3L), in which persistent human-nature dualism may be replaced by relational perspectives. Interstitial activism by museum workers (4D), moving practice activities away from collection alone and drawing in the curation of situated knowledge, may contribute towards 
the potentials surfaced in the analysis for emancipatory change towards a relational ecodecolonial approach to museological practice.

To treat culture-landscape as dialectic may enable revitalised ontological potentials for museological theory and practice. Museums may use the dialectic to reinterpret their relation to physical and cultural spaces and explore the layers of meaning attached to people, sites, and ecologies. The dialectic may disrupt the philosophical shield around collection and undermine the dualist neoliberal ontology. A culture-landscape dialectical frame for museum practice may expand the emancipatory capacities of museums in the Capitalocene.

The dialectic may embrace the idea of "co-engaged meaning making" emergent in Education for Sustainable Development (O’Donoghue et al., 2019, p. 4), which may be expressed in co-curation and co-creation of exhibitions and learning programmes with the narrators of situated knowledge. Such co-creative processes focused on social-ecological learning potentials may be vitalised through museums' character as storytellers (Bedford, 2001; Ciasnocha, Ollson \& Shermis, 2006). Museums may deploy their skills of storytelling and pedagogy (exhibition and learning programmes) in such a way that they become not only collectors and memorialists, but facilitators of oral histories and of active, activist, socialecological knowledge. Curation as an act of storytelling may be creative and collaborative and offers opportunities for museums to become 'story incubators' for people conceived as complex social-ecological entities, members of humanity-in-nature.

In this co-created practice, it is the communities' own narratives that form the backbone of the learning opportunities. The museum acts as facilitator of emergent, situated socialecological narratives, rather than only as a collector (consumer) of things. The museum together with the community may co-create a knowledge commons with points of access for the community, the museum, and the museum's (hopefully) growing community base. Price (2016) has outlined how climate denialists exploit the inability of the scientific method to prove that complex, entangled social-ecological and biophysical processes, such as climate change, are responsible for observed changes in natural systems. The formal scientific method cannot relate evidence at the level of the empirical to the real occurrence of anthropogenic climate change, for instance. Social structures such as museums, however, may facilitate and foreground situated knowledge and evidence for social-ecological crises such as climate change, and thus potentially motivate the cultural and political change that the scientific method cannot.

In practical terms, the situated narrative approach will entail museum curators working in the field to facilitate the emergence of narratives of peoples' relations to culture-landscape. The eco-decolonial situated narrative approach differs from traditional museological approaches in that it is not primarily historical; it is not focused on the past alone, although it has a vital perspective on historical context; and it is not primarily archival. It is an activist and interventionist approach, a mode of knowledge co-production in which the museum is a facilitator of the emergence of new forms of knowledge through, for instance, mediating interactions between intergenerational and scientific knowledge. 
The emancipatory ontological effect of the disruption of collection as an ontological activity thus drives the practical focus of the eco-decolonial mode, in which the primary aim of the situated narrative approach is to generate new knowledge and perspectives on urgent social-ecological issues. The narratives are the core of an active process of knowledge co-production that potentially offers the custodians of intergenerational knowledge active agency in a context, social-ecological crisis, that is normally, or normatively, the preserve of ecological science.

The ontological shift towards a culture-landscape dialectical practice frame may focus museology on a deep engagement with situated social-ecological relationships. Museums may enable agency and empowerment for communities through co-development of projects, which constitute a public voice. This work may emphasise the embeddedness of that voice in a culture-landscape shared with a diversity of living things, and the dialectic may thus expand museological practice so that, to adapt Fiona Cameron's (2015) posthumanist vision, ${ }^{1}$ it invites previously invisible human and non-human social collectives into the civic life of the museum which allows their Capitalocene stories to be told. In this way, the eco-decolonial mode of museology may begin to address museums' crises of relevance and identity.

\section{Notes on Contributor}

Jeffery, Tom

Tom Jeffery is Curator of Exhibitions at Amazwi South African Museum of Literature, and a PhD candidate at Rhodes University's Environmental Learning Research Centre. His research explores relational, interdisciplinary potential for the transformation of museology.

\section{References}

Abungu, G. (2004). Democratising museums and heritage ten years on. South African Museums Association Bulletin, 40(1), 3-5.

Adams, G.K. (2019a). Rift emerges over ICOM's proposed museum definition. Museums Journal, 22 August https://www.museumsassociation.org/museums-journal/ news/22082019-rift-over-icom-definition, visited 3 October 2019.

Adams, G.K. (2019b). News: What is a museum in the $21^{\text {st }}$ century? Museums Association. https://www.museumsassociation.org/news/18092019-what-is-a-museum-in-the21st-century?utm campaign=1577290 19092019\&utm medium=email\&utm source=Museums\%20Association\&dm i=2VBX,XT1M,27M8HC,3JGE0,1, visited 3 October 2019.

Adjor, D.M. \& Kebalo, L. (2018). Does corruption matter for unemployment in SADC countries? Review of Economic and Business Studies, 11(1), 65-92. doi: 10.1515/rebs-2018-0074. 
Allen, F. (2015). The state of the climate justice movement in South Africa. Capitalism nature socialism, 26(2), 46-57. doi: 10.1080/10455752.2015.1017731.

Alonso, M.F. (2008). Can we protect traditional knowledges? In B. de Sousa Santos (Ed.), Another knowledge is possible: Beyond northern epistemologies. New York: Verso. pp. 249-271.

Anderies, J.M., Janssen, M.A. \& Ostrom, E. (2004). A framework to analyze the robustness of social-ecological systems from an institutional perspective. Ecology and Society, 9(1), 1-17. https://www.ecologyandsociety.org/vol9/iss1/art18/

Bakker, K. A. \& Müller, L. (2010). Intangible heritage and community identity in postapartheid South Africa. Museum International, 62(1), 48-56.

Ballantyne, R. \& Uzzel, D. (2011). Looking back and looking forward: The rise of the visitor-centered museum. Curator, 54(10), 85-92.

Bedford, L. (2001). Storytelling: The real work of museums. Curator, 44(1), 27-34.

Bhaskar, R. (1998). The possibility of naturalism: A philosophical critique of the contemporary human sciences. London: Routledge.

Bhaskar, R. (2008). Dialectic: The pulse of freedom. London: Verso.

Bhaskar, R. (2010). Contexts of interdisciplinarity: Interdisciplinarity and climate change. In R. Bhaskar, C. Frank, K. Høyer, P. Næss \& J. Parker (Eds.), Interdisciplinarity and climate change: Transforming knowledge and practice for our global future. London: Routledge. pp. 1-24.

Bhaskar, R. \& Parker, J. (2010). Introduction. In R. Bhaskar, C. Frank, K. Høyer, P. Næss \& J. Parker (Eds.), Interdisciplinarity and climate change: Transforming knowledge and practice for our global future. London: Routledge. pp. vii-xiii.

Budhram, T. \& Geldenhuys, N. (2018). Combating corruption in South Africa: Assessing the performance of investigating and prosecuting agencies. Acta Criminologica: Southern African Journal of Criminology, 31(2), 23-46. doi: 10.10520/EJC-139f4dd49f.

Cameron, F. (2015a). The liquid museum: New institutional ontologies for a complex, uncertain world. In A. Witcomb \& K. Message (Eds.), The international handbooks of museum studies: Museum theory. Milton: John Wiley \& Sons. pp. 345-361.

Cameron, F. (2015b). Ecologizing experimentations: A method and manifesto for composing a post-humanist museum. In F. Cameron \& B. Neilson, B (Eds.), Climate change and museum futures. London: Routledge. pp. 16-33.

Ciasnocha, D., Olsson, M. \& Shermis, N. (2006). The power of storytelling: An interview with Mari-Louise Olsson, the Executive Director of the Museum of Mölndal. Journal of Museum Education, 31(1), 63-69.

Crouch, D. (2010). Flirting with space: Thinking landscape relationally. Cultural Geographies, 17(1). 5-18. doi: 10.1177/1474474009349996.

Crutzen, P.J. (2002). Geology of mankind. Nature, 415, 23.

Corsane, G. (2000). What can South African museums learn from the work of the French sociologist Pierre Bourdieu? South African Museums Association Bulletin, 24(1), 25-30. 
Corsane, G. (2004). Transforming museums and heritage in postcolonial and postapartheid South Africa: The impact of processes of policy formulation and new legislation. Social Analysis, 48(1), 5-15.

De Shuman, A.M. (2020). No longer in extremis. Medium. 15 June. https://medium. com/@andreamontiel23/no-longer-in-extremis-9aa1c5996f35, visited 20 June 2020.

De Sousa Santos, B., Arriscado, J.N. \& Meneses, M.P. (2008). Introduction: Opening up the canon of knowledge and recognition of difference. In B. de Sousa Santos (Ed.), Another knowledge is possible: Beyond northern epistemologies. London: Verso. pp. xix-lxii.

De Sousa Santos, B. (2018). The end of the cognitive empire: The coming of age of epistemologies of the South. London: Duke University Press.

Department of Arts \& Culture. (2009). Review of heritage legislation: Final report, volume 1. http://www.dac.gov.za/sites/default/files/Review\%20of\%20Heritage\%20 Legislation\%20Report.pdf, visited 5 December 2019.

Department of Arts \& Culture. (2017). Revision of the Department of Arts and Culture 1996 White Paper. http://www.dac.gov.za/white-papers, visited 20 May 2020.

Dondolo, L. (2005). Museums and communities: The reconstruction of museums and their practices in post-apartheid South Africa. South African Museums Association Bulletin, 31(1), 68-71.

Dubin, S.C. (2006). Transforming Museums: Mounting Queen Victoria in a democratic South Africa. New York: Palgrave MacMillan.

Engeström, Y. (2015). Learning by Expanding: An Activity-Theoretical approach to developmental research. New York: Cambridge University Press.

Fletcher, A.J. (2017). Applying critical realism in qualitative research: Methodology meets method. International Journal of Social Research Methodology, 20(2), 181-194. doi: 10.1080/13645579.2016.1144401.

Fox, W.L. (2017). The art of the Anthropocene. In J. Newell, L. Robin \& K. Wehner (Eds.), Curating the Future: Museums, communities and climate change. London: Routledge. pp. 196-205.

Garlandini, A. (2017). ICOM Milan 2016: The new responsibilities of museums towards landscapes. Museum international, 69(1-2), 164-175. doi: 10.1111/muse.12160.

Hamer, N. (2019). The hybrid exhibits of the story museum: The child as creative artist and the limits to hands-on participation. Museum \& Society, 17(3), 390-403.

Haraway, D. (1988). Situated knowledges: The science question in feminism and the privilege of partial perspective. Feminist Studies, 14(3), 575-599. doi: $10.2307 / 3178066$.

Hartwig, M. (2008). Introduction. In R. Bhaskar, Dialectic: The pulse of freedom. New York: Routledge. pp. xiii-xxxii.

Helland, L.E.F. \& Lindgren, T. (2016). What goes around comes around: From the coloniality of power to the crisis of civilization. Journal of World-Systems Research, 22(2), 430-462. 
ICOM (International Council of Museums). (2007). Museum definition. https://icom.museum/en/activities/standards-guidelines/museum-definition/ visited 16 July 2019.

ICOM-SA (International Council of Museums-South Africa) \& ICOMOS-SA (International Committee on Monuments and Sites-South Africa). (2016). Declaration on museums and cultural landscapes. http://network.icom.museum/fileadmin/user upload/ minisites/icom-south-africa/pdf/Declaration on Museums and Cultural Landscapes FINAL 2.0.pdf, visited 10 June 2019.

Jeffery, T. (2017). Future-proofing South Africa's cultural museums: Climate change, heritage discourse and cultural landscapes. South African Museums Association Bulletin, 39(1), 19-28. doi: 10.10520/EJC-c85c01dee.

Jeffery, T. (2021). Critical realist philosophy and the possibility of an eco-decolonial museology. Museum and Society, 19(1), 48-70.

Kamga, S.A.D. \& Heleba, S. (2012). Can economic growth translate into access to rights? Challenges faced by institutions in South Africa in ensuring that growth leads to better living standards. International Journal on Human Rights, 9(17), 83-106.

Kristinsdóttir, A. (2017). Toward sustainable museum education practices: Confronting challenges and uncertainties. Museum Management and Curatorship, 32(5), 424-439. doi: 10.1080/09647775.2016.1250104.

Lannegren, O. \& Ito, H. (2017). The end of the ANC era: An analysis of corruption and inequality in South Africa. Journal of Politics and Law, 10(4), 55-59. doi: 10.5539/jpl.v10n4p55

Leino, H. \& Peltomaa, J. (2012). Situated knowledge - situated legitimacy: Consequences of citizen participation in local environmental governance. Policy and Society, 31(2), 159-168. doi: 10.1016/j.polsoc.2012.04.005

Levitz, C. \& Mathers, K. (2000). A poverty of theory, a wealth of activity: Museology and South African museums. South African Museums Association Bulletin, 24(1), 18-21.

Lotz-Sisitka, H. (2016). Absenting absence: Expanding zones of proximal development in environmental learning processes. In L. Price \& H. Lotz-Sisitka (Eds.), Critical realism, environmental learning and social-ecological change. London: Routledge. pp. 318-339.

Lotz-Sisitka, H. \& Price, L. (2016). Why critical realism, environmental learning and social-ecological change? Introducing the book. In L. Price \& H. Lotz-Sisitka (Eds.), Critical Realism, Environmental Learning and Social-Ecological Change. London: Routledge. pp. 1-18.

Lotz-Sisitka, H., Wals, A.E.J., Kronlid, D., \& McGarry, D. (2015). Transformative, transgressive social learning: Rethinking higher education pedagogy in times of systemic global dysfunction. Current Opinion in Environmental Sustainability, 16, 73-80. doi:10.1016/j.cosust.2015.07.018.

Lotz-Sisitka, H., Belay, M.A., Mphepo, G., Chaves, M., Macintyre, T., Pesanayi, T., ... McGarry, D. (2016). Co-designing research on transgressive learning in times of climate change. Current Opinion in Environmental Sustainability, 20, 50-55. doi: 10.1016/j.cosust.2016.04.004. 
Luengo, M. (2015). Foreword. In K. Taylor, A. St Clair \& N. Mitchell (Eds.), Conserving cultural landscapes: Challenges and new directions. London: Routledge.p. xi-xviii.

Macdonald, S. (2015). Is 'difficult heritage' still difficult? Why public acknowledgment of past perpetration may no longer be so unsettling to collective identities. Museum International, 67(1-4), 6-22.

Mahony, E. (2017). Opening spaces of resistance in the corporatized cultural institution: Liberate Tate and the Art Not Oil Coalition. Museum \& Society, 15(2), 126-141.

Marschall, S. (2005). Making money with memories: The fusion of heritage, tourism and identity formation in South Africa. Historia, 50(1), 103-122.

Martin, M. (2000). Theory into practice, practice into theory. South African Museums Association Bulletin, 24(1), 11-17.

Mdanda, S. (2016). Museums and democratic education: How museums were transformed after the 1994 elections in South Africa. South African Museums Association Bulletin, 38(1) 47-57.

Meskell, L. (2012). The nature of heritage: The new South Africa. Sussex: Wiley-Blackwell.

Mngqolo, S. (2010). Voices within our exhibitions. South African Museums Association Bulletin, 33(1) 70.

Mukute, M. (2016). Dialectical critical realism and Cultural Historical Activity Theory (CHAT): Exploring and expanding learning processes in sustainable agriculture workplace contexts. In L. Price \& H. Lotz-Sisitka (Eds.), Critical Realism, Environmental Learning and Social-Ecological Change. London: Routledge. pp. 190-211.

Mungwini, P. (2013). African modernities and the critical reappropriation of indigenous knowledges: Towards a polycentric global epistemology. International Journal of African Renaissance Studies - Multi-, Inter- and Transdisciplinarity, 8(1), 78-93. doi: 10.1080/18186874.2013.834556.

Moore, J.W. (2017). 'The Capitalocene, part I: On the nature and origins of our ecological crisis. Journal of Peasant Studies, 44(3), 594-630. doi:10.1080/03066150.2016.1235036.

Morgan, J. \& Macdonald, S. (2020). De-growing museum collections for new heritage futures. International Journal of Heritage Studies, 26(1), 56-70. doi:10.1080/13527258.2018.1530289.

Mosely, E. (2007). Visualizing apartheid: Contemporary art and collective memory during South Africa's transition to democracy. Antipoda, 5, 97-119.

Nattrass, N. (2014). A South African variety of capitalism? New Political Economy, 19(1), 56-78. doi: 10.1080/13563467.2013.768610.

Newell, J., Robin, L. \& Wehner, K. (2017). Introduction. In J. Newell, L. Robin \& K. Wehner (Eds.), Curating the future: Museums, communities and climate change. London: Routledge. pp. 1-16.

Nixon, R. (2011). Slow Violence and the Environmentalism of the Poor. Cambridge, Massachusetts: Harvard University Press. 
Nixon, R. (2017). The Anthropocene and environmental justice. In J. Newell, L. Robin $\&$ K. Wehner (Eds.), Curating the Future: Museums, communities and climate change. London: Routledge. pp. 23-31.

Norrie, A. (2010). Dialectic and difference: Dialectical critical realism and the grounds of justice. London: Routledge.

Ntsoane, O. (2002). lndigenisation of museums and de-fossilisation of knowledge: Towards a future perfect place. South African Museums Association Bulletin, 28(1), 27-31.

O’Donoghue, R., Sandoval-Rivera, Juan, C.A. \& Payyappallimana, U. (2019). Landscape, memory and learning to change in changing worlds: Contemplating intergenerational learning and traditional knowledge practices within social-ecological landscapes of change. Southern African Journal of Environmental Education, 35, 1-34.

Pearce, S.M. (2003). Interpreting Objects and Collections. London: Routledge.

Phillips, R.B. (2019). 'Making fun' of the museum: Multi-disciplinarity, holism, and the 'return of curiosity'. Museum and Society, 17(3), 316-341.

Philpott, C. (2014). Socioculturally situated narratives as co-authors of student teachers' learning from experience. Teaching Education, 25(4), 391-409. doi: 10.1080/10476210.2014.908839.

Plumwood, V. (2002). Decolonising relationships with nature. Philosophy Activism Nature, 2, 7-30.

Price, L. (2016). Key critical realist concepts for environmental educators. In L. Price \& H. Lotz-Sisitka (Eds.), Critical Realism, Environmental Learning and Social-Ecological Change. London: Routledge. pp. 18-39.

Rall, M. (2018). Across time of three South African San exhibitions: Reflecting on colonialism, apartheid and decolonisation. South African Museums Association Bulletin, 40(1), 11-22.

Rassool, C. (2000). The rise of heritage and the reconstitution of history in South Africa. Kronos, 26(1), 1-21.

Rassool, C. (2016). Red Mandela: Contests of auto-biography and auto/biography in South Africa. Kronos, 42, 195-213.

Robin, L., Avango, D., Keogh, L., Möllers, N. \& Trischler, H. (2017). Displaying the Anthropocene in and beyond museums. In J. Newell, L. Robin \& K. Wehner (Eds.), Curating the Future: Museums, communities and climate change. London: Routledge. pp. 252-266.

Rogage, K., Kirk, D., Charlton, J., Nally, C., Swords, J. \& Watson, R. (2021). Memoryscapes: Designing situated narratives of place through heritage collections. International Journal of Human-Computer Interaction, 37, 1-21. doi: 10.1080/10447318.2020.1865004

Rosenberg, E. (2020a). Synthesis and elaboration of critical realist methodology for green skills research. In E. Rosenberg, P. Ramsarup \& H. Lotz-Sisitka (Eds.), Green Skills Research in South Africa: Models, cases and methods. Oxon: Routledge. pp. 192-207. 
Rosenberg, E. (2020b). Special issue: Education for sustainability in a time of crises. Editorial Part 1, June 2020. Southern African Journal of Environmental Education, 36, 1-7. doi: 10.4314/sajee.v36i1.1.

Roux, N. (2018). 'A house for dead people': Memory and spatial transformation in Red Location, South Africa. Social \& Cultural Geography, 19(4), 407-428. doi: 10.1080/14649365.2017.1280614.

Sabai, D. (2016). Indigenous knowledge and critical realism on the eastern coast of Tanzania. In L. Price, L. \& H. Lotz-Sisitka (Eds.), Critical Realism, Environmental Learning and Social-Ecological Change. London: Routledge. pp. 178-189.

Sandahl, J. (2018). International Council of Museums Standing Committee for Museum definition, prospects and potentials: Report and recommendations. ICOM (International Council of Museums). 19 June. https://icom.museum/en/activities/ standards-guidelines/museum-definition/, visited 14 October 2019.

Sandahl, J. (2019). Definitions are dynamic, not static. Museums Journal, 119 (12). https://www.museumsassociation.org/museums-journal/comment/01122019definitions-are-dynamic-not-static?utm campaign=1644717 $12122019 \& u t m$ medium=email\&utm source=Museums\%20Association\&dm i=2VBX,Z92L,7AK7Z8,3PDZT,1 visited 13 December 2019.

Schudel, I.J. (2017). Modelling dialectical processes in environmental learning: An elaboration of Roy Bhaskar's onto-axiological chain. Journal of Critical Realism, 16(2), 163-183. doi:10.1080/14767430.2017.1288061.

Shoba, N. (2005). Community museums: An Insight into the socio-economic, environmental and cultural impacts on community museums in the Eastern Cape. South African Museums Association Bulletin, 31(1), 26.

Smith, C. (2014). Post-modernising the museum: The Ration Shed. Historical Encounters, 1(1), 32-49.

Sodano, C. (2017). Cultural landscapes in international charters. Museum International, 69(12), 80-85. doi: 10.1111/muse.12152.

Soudien, C. (2008). Emerging discourses around identity in new South African museum exhibitions. Interventions, 10(2), 207-221. doi: 10.1080/13698010802145119.

South African Cultural Observatory. (2018). Minister Mthethwa interaction with the creative industries. https://www.southafricanculturalobservatory.org.za/article/ minister-mthethwa-interaction-with-the-creative-industries, visited 13 May 2020.

South African Government. (2011). Mzansi's Golden Economy: Contribution of the arts, culture and heritage sector to the New Growth Path. https://www.gov.za/documents/ mzansis-golden-economy-contribution-arts-culture-and-heritage-sector-new-growthpath, visited 13 May 2020.

Thomas, N. (2016). The Ascendancy of the Museum. London: Reaktion. 
Togo, M. (2016). Underlabouring systems thinking with critical realism in understanding Rhodes University's response to the sustainability imperative. In L. Price, L. \& H. LotzSisitka (Eds.), Critical Realism, Environmental Learning and Social-Ecological Change. London: Routledge. pp. 85-97.

UNESCO (United Nations Educational, Scientific and Cultural Organization). (1972). Convention concerning the protection of the world cultural and natural heritage. https://whc.unesco.org/en/conventiontext/, visited 6 November 2019.

UNESCO (United Nations Educational, Scientific and Cultural Organization). (2017). Operational Guidelines for the Implementation of the World Heritage Convention. https://whc.unesco.org/en/guidelines/, visited 18 June 2019.

Vollgraaff, H. (2004). Editorial. South African Museums Association Bulletin, 30(1), 2.

Vergo, P. (1989). Introduction. In P. Vergo (Ed.), The New Museology. Bath: Reaktion. pp. 1-5.

Vollgraaff, H. (2018). Revitalising the South African museum sector: New museological trends. In P. Ngulube (Ed.), Handbook of Research on Heritage Management and Preservation. Hershey PA: IGI Global. pp. 372-395.

Walker, B., Holling, C. S., Carpenter, S.R. \& Kinzig, A. (2004). Resilience, adaptability and transformability in social-ecological systems. Ecology and Society, 9(2). https://www.ecologyandsociety.org/vol9/iss2/art5/.

Wehner, K. (2017). Towards an ecological museology: Responding to the animal-objects of the Australian Institute of Anatomy collection. In J. Newell, L. Robin \& K. Wehner (Eds.), Curating the Future: Museums, communities and climate change. London: Routledge. pp. 85-100.

Weil, S. (1999). From being about something to being for somebody: The ongoing transformation of the American museum. Daedalus, 128(3), 229-258.

Witz, L., Rassool, C. \& Minkley, G. (2001). Repackaging the past for South African tourism. Daedalus, 130(1), 277-296.

Zuma, B. (2018). The extent to which South African museums surrendered to political undertones. Museum International, 70(3-4), 38-47. doi: 10.1111/muse.12208.

\section{Endnotes}

1 Cameron framed her post-humanist perspective as a means to move beyond Cartesian rationality, which is the foundation of museological dualism and emphasises humans as hierarchically superior to nature and non-human beings. She reframes museology in a terms of relational connections that "compose different museum worlds, in respect to alternative ways we can entangle ourselves with places [and] nonhumans" (2015b, p. 24). The post-human vision decentres humanity in the ontology of ecology. Most significantly, Cameron envisions non-human beings as entities with rights of citizenship, which is a means to ensure the non-human right to justice. 